\title{
Synthesis of zirconia-based solid acid nanoparticles for fuel cell application
}

\author{
Rudzani A. Sigwadi ${ }^{1 *}$
}

\author{
Sipho E. Mavundla ${ }^{2}$
}

Nosipho Moloto $^{3}$

Touhami Mokrani ${ }^{1}$

1 Department of Chemical Engineering, University of South Africa, Christian de Wet Road \& Pioneer Avenue, FloridaPrivate Bag X6, Johannesburg 1710, South Africa

2 Department of Chemistry, University of Zululand, Private Bag x 1001, KwaDlangezwa, 3886, South Africa

3 Molecular Science Institute, School of Chemistry, University of the Witwatersrand, Private Bag 03, Wits 2050, Johannesburg, South Africa

\begin{abstract}
Zirconia nanoparticles were prepared by the precipitation and ageing methods. The precipitation method was performed by adding ammonium solution to the aqueous solution of zirconium chloride at room temperature. The ageing method was performed by leaving the precipitate formed in the mother liquor in the glass beaker for 48 hours at ambient temperatures. The nanoparticles from both methods were further sulphated and phosphated to increase their acid sites. The materials prepared were characterised by X-ray diffraction (XRD), thermo-gravimetric analysis (TGA), Brunauer-EmmettTeller (BET), transmission electron microscopy (TEM) and scanning electron microscopy (SEM) methods. The XRD results showed that the nanoparticles prepared by the precipitation method contained mixed phases of tetragonal and monoclinic phases, whereas the nanoparticles prepared by ageing method had only tetragonal phase. The TEM results showed that phosphated and sulphated zirconia nanoparticles obtained from the ageing method had a smaller particle size (10-12 nm) than the nanoparticles of approximately $25-30 \mathrm{~nm}$ prepared by precipitation only. The BET results showed that the $\mathrm{ZrO}_{2}$ nanoparticles surface area increased from 32 to $72 \mathrm{~m}^{2} / \mathrm{g}$ when aged.
\end{abstract}

Keywords: nanoparticles, precipitation, zirconium oxide, aging, monoclinic, tetragonal, phosphated zirconia, sulphated zirconia, pore volume, pore diameter

\footnotetext{
* Corresponding author Tel : +27 (0)11 6709462

Email:sigwara@unisa.ac za

DOI: http://dx.doi.org/10.17159/2413-3051/2016/v27i2a1342
}

\section{Introduction}

In the last three decades there has been increased interest in alternative energy research, given that fossil fuels are not going to be with us forever. Among alternative energies, fuel cell technology is one of the most studied because of its potential use in automobiles, electronics and power plants (Wang et al., 2000). The interest in fuel cells has led to an extensive investigation of proton-conducting membranes (e.g. polymeric and organic/inorganic nanocomposite membrane) (Stoychev et al., 2000).

A proton-conducting membrane is the key component of a fuel cell system. Perfluorosulphonated membranes are widely used as proton conductors, including Nafion series (DuPont) with Nafion 117 as the preferred membrane for direct methanol fuel cells. Nafion is the state-of-the-art commercial membrane and performs well in a hydrated environment; its proton conductivity has a strong dependence on water content, but if it is not properly hydrated, proton conduction becomes slow (Zawodzinski, et al., 1995). At higher temperatures, the PEM will dehydrate and lose proton conductivity, and may result in irreversible mechanical damage. However, higher working temperatures are favourable for the kinetics of a platinum Pt catalyst and improve its tolerance to carbon monoxide poisoning (Costamagna et al., 2002). A Nafion membrane has an osmotic swelling problem and is also potentially dissolved in methanol solution when the methanol concentration and temperature are increased (Kleina, et al., 2005).

The efforts to improve membrane properties, e.g. increasing the working temperature above $100{ }^{\circ} \mathrm{C}$, increasing water content and mechanical strength as well as organic and inorganic nanocom- 
posite membranes are extensively investigated. Nanoparticles of metal oxides are used to modify a Nafion membrane in order to improve its water retention, thermal stability, proton conductivity and methanol permeability (Savadogo, 2004). It has been demonstrated that the incorporation of metal oxides in the form of nanoparticles improves water retention and the thermo-mechanical stability of the membranes (Savadogo, 2004). These modified Nafion nanocomposite membranes with inorganic nanoparticles have been designed to run at temperatures above $100{ }^{\circ} \mathrm{C}$ because higher temperature operation reduces the impact of carbon monoxide poisoning, allows attainment of high power density and reduces cathode flooding as water is produced as vapour (Hara and Miyayama, 2004).

Among metal oxides, zirconium oxide $\left(\mathrm{ZrO}_{2}\right)$ nanoparticles have been widely studied because of their high thermal and chemical stability, mechanical strength, chemical inertness, wear and corrosion resistance as well as high water retention (Ranjbar et al., 2012). The $\mathrm{ZrO}_{2}$ nanoparticles can exist in a number of polymorphs at atmospheric pressure and are monoclinic, tetragonal and cubic (Navarra et al., 2008). The tetragonal phase of $\mathrm{ZrO}_{2}$ nanoparticles is considered to be the one that is highly catalytic, with low thermal conductivity and thermal expansion coefficient compared with the others, rendering them suitable for use as oxide ion conductors in higher temperature sensors (Adjemian et al., 2006; Adjemian et al., 2002 ; Adjemian et al., $2002_{\text {b }}$; Costamagna et al., 2002). This tetragonal $\mathrm{ZrO}_{2}$ is also used as a catalyst and catalyst support for various gas phase reactions (Casciola et al., 2008; Jian-Hua et al., 2008).

One of the disadvantages of zirconium is its low surface area, acidity and conductivity. This problem can be solved by modifying zirconium nanoparticles with acids such as sulphates (Shao et al., 2006; Xu et al., 2005; Adamski et al.,2008; Mekhemer \& Ismail, 2000; Jiao et al., 2003) and phosphates (Ray et al., 2000) to yield solid acids of a wide range of strengths. This acid-modified zirconia has been found to increase water retention, improve proton conductivity and reduce the methanol crossover in the membrane (Zhou et al., 2006; Bondars et al., 1995; Chuah et al., 2001) and be more stable than other solid super acids (Wang et al., 2006).

This aim of the current work is to modify zirconium nanoparticles in order to make them suitable as additives to Nafion membranes, by adding sulphates and phosphates and by also increasing their pore volume and surface area in order to increase water retention in the membrane.

\section{Experimental methods 2.1. Reagents}

Zirconium diammonium hydrogen phosphate
$\left(\left(\mathrm{NH}_{4}\right)_{2} \mathrm{HPO}_{4}\right)$, Zirconium oxychloride hydrate $\left(\mathrm{ZrOCl}_{2} .8 \mathrm{H}_{2} \mathrm{O}\right)$, silver nitrate $\left(\mathrm{AgNO}_{3}\right)$, sulphuric acid $\left(\mathrm{H}_{2} \mathrm{SO}_{4}\right)$ and ammonia solution $\left(\mathrm{NH}_{3}\right)$ were purchased from Merck. All the chemicals were used as received.

\subsection{Preparation of zirconium oxide by precipitation.}

The $\mathrm{ZrO}_{2}$ nanoparticles were prepared by the precipitation method; zirconium oxychloride hydrate $\left(\mathrm{ZrOCl}_{2} .8 \mathrm{H}_{2} \mathrm{O}\right)$ and ammonia $\left(\mathrm{NH}_{3}\right)$ were used as starting materials. Zirconium hydroxide's precipitation $\left(\mathrm{Zr}(\mathrm{OH})_{4}\right)$ was obtained by adding an $\mathrm{NH}_{3}$ aqueous solution drop-wise to the aqueous solution of $0.2 \mathrm{M} \mathrm{ZrOCl}_{2} \cdot 8 \mathrm{H}_{2} \mathrm{O}$ at room temperature while vigorously stirring until the desired $\mathrm{pH}$ of 10 was reached. The precipitate was divided into two parts. The one part of the precipitate was washed with deionised water until the chlorine ions $\left(\mathrm{Cl}^{-}\right)$were not detected by the silver nitrate $\left(\mathrm{AgNO}_{3}\right)$ test and filtered to obtain a wet powder of $\mathrm{Zr}(\mathrm{OH})_{4}$. The wet powder was dried in an oven at $100{ }^{\circ} \mathrm{C}$ overnight. Zirconium oxide nanopowder was obtained through the calcination of the dried zirconium hydroxide at $600{ }^{\circ} \mathrm{C}$ for 6 hours.

\subsection{Preparation of zirconium oxide by ageing method}

The remaining part of the precipitate formed as described in Section 2.2 was aged in the mother liquor by leaving it in the glass beaker for 48 hours at ambient temperature. The precipitate was filtered, then washed and calcined according to the procedure described above.

\subsection{Preparation of sulphated zirconia}

Sulphated zirconia $\left(\mathrm{S}_{-} \mathrm{ZrO}_{2}\right)$ nanopowder was prepared by vigorously stirring the dried aged or unaged $\mathrm{ZrO}_{2}$ nanopowder obtained from section 2.2 and 2.3 in $0.5 \mathrm{M} \mathrm{H}_{2} \mathrm{SO}_{4}$ for 30 minutes at room temperature. The resulting solid was filtered and dried at $100{ }^{\circ} \mathrm{C}$ for 48 hours. The dried $\mathrm{S}-\mathrm{ZrO}_{2}$ nanopowder was then calcined at $600{ }^{\circ} \mathrm{C}$ for 2 hours and the resulting particles were ground to an ultra-fine powder using a mortar and pestle (Roberts et al, 2015).

\subsection{Preparation of phosphated zirconia}

The phosphated zirconia $\left(\mathrm{P}-\mathrm{ZrO}_{2}\right)$ nanoparticles were prepared from aged and un-aged $\mathrm{ZrO}_{2}$ nanoparticles (obtained as described in Sections 2.2 and 2.2) using diammonium hydrogen phosphate $\left(\left(\mathrm{NH}_{4}\right)_{2} \mathrm{HPO}_{4}\right)$ solution. A portion of the $\mathrm{ZrO}_{2}$ nanopowder was dissolved in an aqueous solution of $\left(\mathrm{NH}_{4}\right)_{2} \mathrm{HPO}_{4}$. The solution was stirred for 30 minutes using a magnetic stirrer at room temperature for 30 minutes. The $\mathrm{P}-\mathrm{ZrO}_{2}$ nanoparticle suspension obtained was filtered and dried at $100{ }^{\circ} \mathrm{C}$ for 48 hours, followed by calcining at $600{ }^{\circ} \mathrm{C}$ for 2 
hours. The resulting particles were ground to an ultra-fine powder using a mortar and pestle.

\section{Characterisation}

The XRD analysis was performed using a Philips Xray automated diffractometer with $\mathrm{Cu} \mathrm{K}$ radiation source. The analysed material was finely grounded and homogenised. Samples were scanned in a continuous mode from $10-90^{\circ}$ (2 theta) with a scanning rate of $0.026 \%$ s. The thermal properties of the samples were studied by thermal gravimetric analysis (TGA) under nitrogen flow. The TGA experiment was carried out using Model 1500 Simultaneous Thermal Analyser (made by Rheometric Scientific limited, United Kingdom), in an inert atmosphere supplied by nitrogen gas at a heating rate of 10 ${ }^{\circ} \mathrm{C} /$ min from $50^{\circ} \mathrm{C}$ to $1000^{\circ} \mathrm{C}$.

A BET surface area instrument (Micromeritics Accelerated SA and Porisimetry 2010 system) was used to determine information such as gas uptake, micropore volume ( $\mathrm{t}$-plot method), and pore size distribution from adsorption and desorption isotherms. In BET surface area analysis, a dry sample was evacuated of all gas and cooled to $77 \mathrm{~K}$ using liquid nitrogen. The particle size was calculated by using Equation 1.

$$
S=\frac{6 \times 10^{3}}{\rho D_{B E T}}
$$

where $\rho$ is the theoretical density of the materials which equal to $6.27 \mathrm{~g} / \mathrm{cm}^{3}$ (Parera, 1992) and $D_{B E T}$ is the particle size in $\mathrm{nm}$.

The matrix surface and cross-section of the synthesised nanopowder morphology were investigated by means of SEM. Scanning electron microscope images were obtained on a Hitachi x650. This technique involves the interaction of the sample with electrons, which results in a secondary effect that is detected and measured. High-resolution transmission electron microscopy (HRTEM) was used to estimate their particle size and observe the morphology.

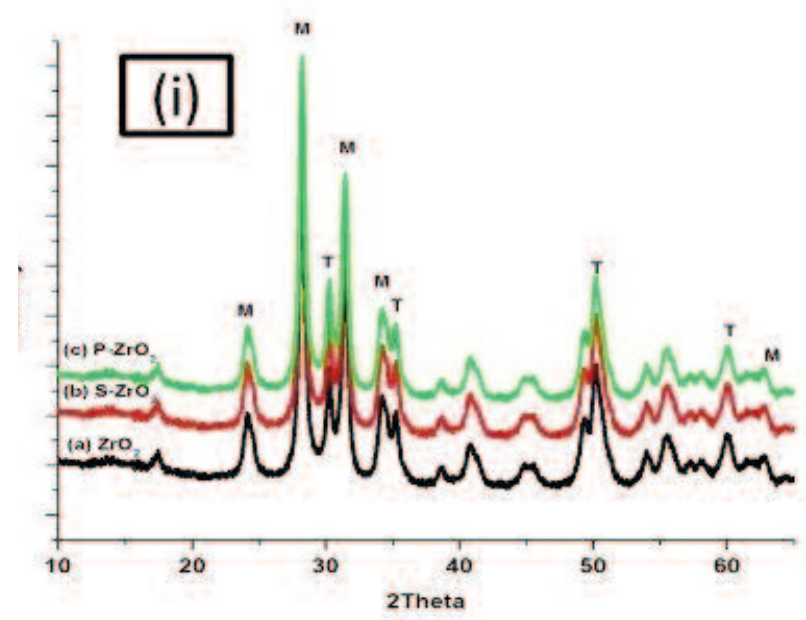

\section{Results}

3.1. The X-ray diffraction analysis of $\mathrm{ZrO}_{2}$,

\section{$\mathrm{S}-\mathrm{ZrO}_{2}$ and $\mathrm{P}-\mathrm{ZrO}_{2}$ nanoparticles}

Figure 1(i) shows the diffraction patterns of the (a) $\mathrm{ZrO}_{2}$, (b) $\mathrm{S}-\mathrm{ZrO}_{2}$, and (c) $\mathrm{P}-\mathrm{ZrO}_{2}$ nanoparticles prepared without ageing. The crystallinity of materials in Figure 1(i) is evidenced by sharper diffraction peaks at respective diffraction angles. The XRD did not show any significant difference between $\mathrm{ZrO}_{2}$ (Figure 1(i)(a)) and other modified $\mathrm{ZrO}_{2}$ (Figure 1(i)(b) and Figure 1(i)(c)). All the samples exhibited the mixture of monoclinic and tetragonal phase. The major peaks appeared at $24.4^{\circ}, 28.2^{\circ}, 30.5^{\circ}$, $34.5^{\circ}$ and $62.3^{\circ}$ (2theta). The strongest diffraction peak of monoclinic structure which appeared at $28.2^{\circ}$ (2theta) was due to the (111) plane, and the major peak for the tetragonal structure seen at $30.5^{\circ}$ (2theta) was attributed to the (101) plane. The obtained structures are comparable to the JCPDS data (Card No.37-1484) (Jiao et al., 2003; Ray et al., 2000) for the monoclinic and standard JCPDS data (Card No.17-0923) (Zhou et al., 2006) for the tetragonal structure. Comparing the intensity of the monoclinic and tetragonal peaks shows that the monoclinic peaks are more intense than tetragonal peaks and it can be concluded that the samples contain more monoclinic structure than tetragonal.

The XRD patterns of the samples synthesised by aging method are shown in Figure 1(ii). All the samples showed similar diffraction patterns at $30.2^{\circ}$, $50.2^{\circ}$ and $60.2^{\circ}$ (2theta) which are characteristics of zirconium in a tetragonal phase and can be indexed to the standard pattern of the tetragonal phase of $\mathrm{ZrO}_{2}$, which is in good agreement with reported data (JCPDS No.81-1544) (Chuah et al., 2001). The peaks at $30.2^{\circ}, 50.2^{\circ}$ and $60.2^{\circ}$ correspond to the planes at 101,112 and 211 respectively. These XRD patterns show that these materials are amorphous, as evident by peaks and humps. From these results it can be deduced that the slow ageing of samples favoured the tetragonal structure growth, the monoclinic peaks completely disap-

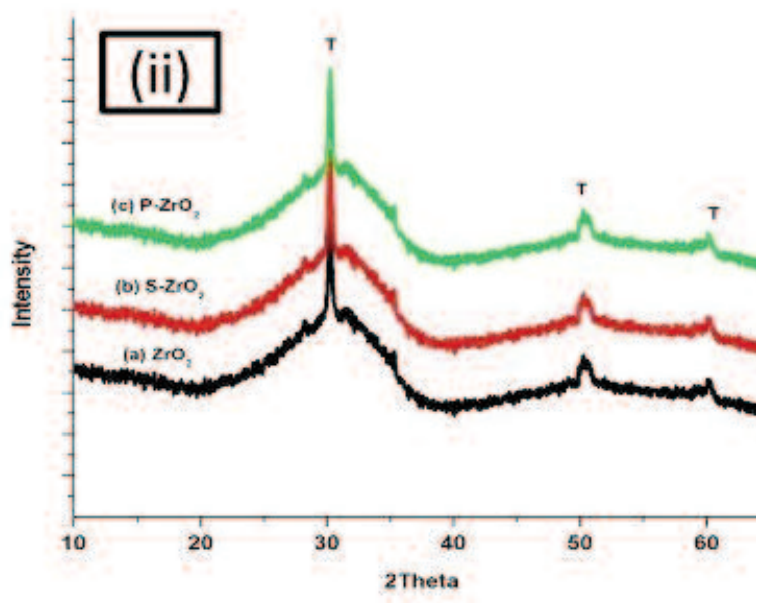

Figure 1: XRD patterns of (a) $\mathrm{ZrO}_{2}$, (b) $\mathrm{S}-\mathrm{ZrO}_{2}$ and (c) $\mathrm{P}^{-\mathrm{ZrO}_{2}}$ nanoparticles (i) un-aged and (ii) aged 

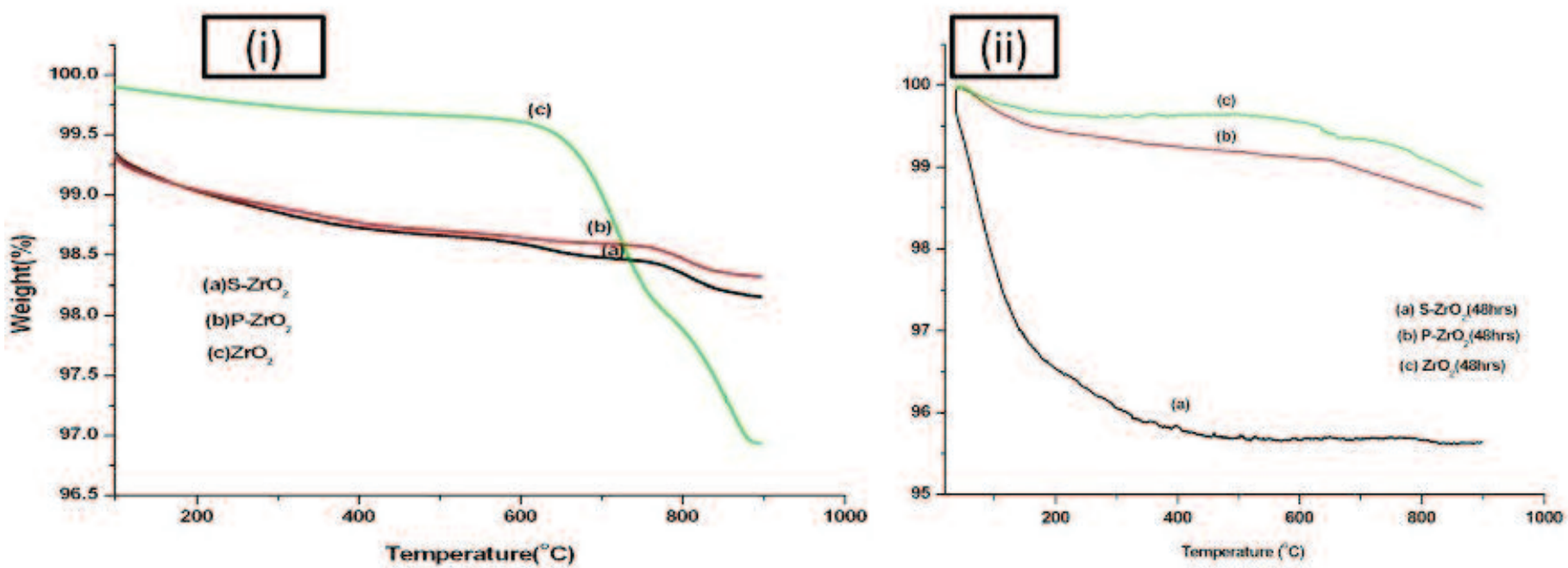

Figure 2: Thermogravimetric analysis of (a) $\mathrm{S}-\mathrm{ZrO}_{2}$, (b) $\mathrm{P}-\mathrm{ZrO}_{2}$ and (c) $\mathrm{ZrO}_{2}$ nanoparticles (i) un-aged and (ii) aged

peared. This ageing method can be used for single phase zirconium at ambient temperature, whereas other researchers (Hsieh, 1996) find that the single phase can be achieved at temperatures of 950 $1230{ }^{\circ} \mathrm{C}$.

\subsection{Powder thermo-gravimetric analysis}

The $\mathrm{ZrO}_{2}, \mathrm{P}-\mathrm{ZrO}_{2}$ and $\mathrm{S}-\mathrm{ZrO}_{2}$ nanopowder were evaluated by means of thermo-gravimetric analysis (TGA). Figure 2 indicates that the thermal decomposition process occurs in two weight-loss stages. The TGA curve in Figure 2(i) (a) indicates that the thermal decomposition occurs initially between 40 ${ }^{\circ} \mathrm{C}$ and $200{ }^{\circ} \mathrm{C}$, with mass loss of $0.4 \%$ associated to dehydration. The second stage of thermal decomposition is related to decomposition of sulphate and carbonaceous phase decomposition, respectively. The total weight loss of original material reaches about $3.2 \%$. For the phosphated zirconia, Figure 2(i)(b) shows the initial weight loss from 20-300 ${ }^{\circ} \mathrm{C}$, which can be attributed to the loss of moisture (Smitha et al., 2003). No further weight loss could be detected up to $900{ }^{\circ} \mathrm{C}$, indicating the thermal stability of the phosphate species incorporated. The TGA curve $2(\mathrm{i})(\mathrm{c})$ indicates that pure $\mathrm{ZrO}_{2}$ has little loss of its original weight on heating up to $600{ }^{\circ} \mathrm{C}$. This may be due to the dehydration occurring through the loss of water molecules from adjacent -OH groups. Figure 2(ii) also shows two weights loss stages which are the same as in Figure 2(i) except that in Figure 2(ii) the weight losses are more stabilised.

\subsection{Brunauer-Emmett-Teller}

The BET specific surface areas of $\mathrm{ZrO}_{2}, \mathrm{~S}-\mathrm{ZrO}_{2}$ and $\mathrm{P}-\mathrm{ZrO}_{2}$ nanoparticles materials calcinated at $600^{\circ} \mathrm{C}$ temperature are listed in Table 1 and Figure 3. The specific surface area of $\mathrm{ZrO}_{2}$ nanoparticles materials was found to be $33 \mathrm{~m}^{2} / \mathrm{g}$ which is larger than the 23
Table 1: BET surface area for $\mathrm{ZrO}_{2}, \mathrm{~S}-\mathrm{ZrO}_{2}$ and $\mathrm{P}-\mathrm{ZrO}_{2}$ nanoparticles calcinated at $600{ }^{\circ} \mathrm{C}$

\begin{tabular}{lccc}
\hline Samples & $\begin{array}{c}\text { BET surface } \\
\text { area }\left(\mathrm{m}^{2} / \mathrm{g}\right)\end{array}$ & $\begin{array}{c}\text { Particle } \\
\text { size }(\mathrm{nm})\end{array}$ & $\begin{array}{c}\text { Pore volume } \\
\left(\mathrm{cm}^{3} / \mathrm{g}\right)\end{array}$ \\
\hline $\mathrm{ZrO}_{2}$ & 33 & 29 & 0.08 \\
\hline${\mathrm{S}-\mathrm{ZrO}_{2}}_{\mathrm{P} \mathrm{ZrO}_{2}}^{39}$ & 37 & 24 & 0.09 \\
\hline $\mathrm{ZrO}_{2}$ (aged) & 72 & 26 & 0.07 \\
\hline $\mathrm{S}-\mathrm{ZrO}_{2}$ (aged) & 79 & 13 & 0.13 \\
\hline $\mathrm{P}-\mathrm{ZrO}_{2}$ (aged) & 77 & 12 & 0.16 \\
\hline
\end{tabular}

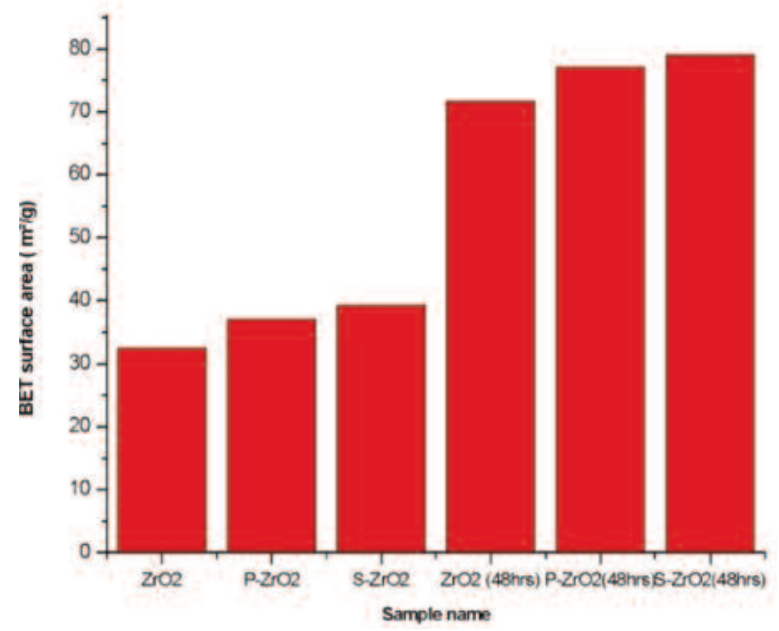

Figure 3: BET surface areas of the nanoparticles calcined at $600{ }^{\circ} \mathrm{C}$

$\mathrm{m}^{2} / \mathrm{g}$ obtained by Chuah et al. (1996). The specific surface area of $\mathrm{ZrO}_{2}$ nanoparticles increased from 33 to $39 \mathrm{~m}^{2} / \mathrm{g}$ when they were modified by sulphuric acid. This indicated that the presence of suphate strongly influences the surface acidity of $\mathrm{ZrO}_{2}$ nanoparticles (Tanabe \& Yamaguchi, 1994). Zirconia modified with sulphates exhibits superior catalytic activity. The presence of sulphates increas- 
es the stability of zirconia as well as the content of the tetragonal crystal phase, which is the one believed to be catalytically active (Zarubica et al., 2009). It has been reported that $\mathrm{S}-\mathrm{ZrO}_{2}$ exhibited a Hammett acid strength $H_{0}$ of -16.03 , whereas for $100 \%$ sulphuric acid it is only -11.99 and shows higher strength (Yadav \& Nair, 1999). The modification with diammonium hydrogen phosphate acid also increases the specific surface areas to $37 \mathrm{~m}^{2} / \mathrm{g}$, which is high in comparison with unmodified $\mathrm{ZrO}_{2}$, as has also been observed by other researchers (Abbattista et al., 1990). Figure 3 shows that the nanoparticles obtained from the ageing method had an enhanced specific surface area, which is necessary for the application of zirconia nanoparticles as catalyst support in fuel cells. The results show the specific surface area doubled when the aging method was used, going from 33 to 72,39 to 79 and 37 to $77 \mathrm{~m}^{2} / \mathrm{g}$ for $\mathrm{ZrO}_{2}, \mathrm{~S}-\mathrm{ZrO}_{2}$ and $\mathrm{P}-\mathrm{ZrO}_{2}$ respectively. Our results are in agreement with the results obtained by other researchers (Jakubus et al., 2003). This indicates that by aging $\mathrm{ZrO}_{2}$ nanoparticles the surface area also increases, which make them suitable for fuel cell application. The particle size of nanoparticles was reduced by half when the $\mathrm{ZrO}_{2}$ nanoparticles were aged. A slightly increase of pore volume was observed upon the sulphated zirconia with pore volume ranges of 0.09 $0.16 \mathrm{~cm}^{3} / \mathrm{g}$ when compared to the un-sulphated zir- conia with pore volume ranges of $0.08-0.13 \mathrm{~cm}^{3} / \mathrm{g}$. These properties are good for the application of $\mathrm{ZrO}_{2}$ in fuel cell membranes.

\subsection{Scanning electron microscopy}

Figure 4 shows SEM images of aged (Figure 4(a-c) and Figure 4(d-f) un-aged nanoparticles. It is observable that all nanoparticles are aggregated into clusters and their morphology is mostly spherical. This has also been observed elsewhere (Ranjbar et al., 2012; Lim et al., 2013). These nanoparticles are in the form of agglomerates but close inspection reveals that in Figure 4(b) and (c) they are less agglomerated than in Figure 4(a), which might be due to acid solutions in nanoparticles reducing their agglomeration. The aged nanoparticles are more agglomerated than un-aged ones. This might be due to their small size, which was a results of ageing. It was not possible to estimate the particle size, but it can be observed that agglomerates from aged nanoparticles are made up of clusters of smaller nanoparticles. This was confirmed by our BET results, which showed that the aged nanoparticles were half the size of unaged ones.

\subsection{Transmission electron microscopy}

The morphology and size information of the $\mathrm{ZrO}_{2}$ nanoparticles was further investigated by TEM

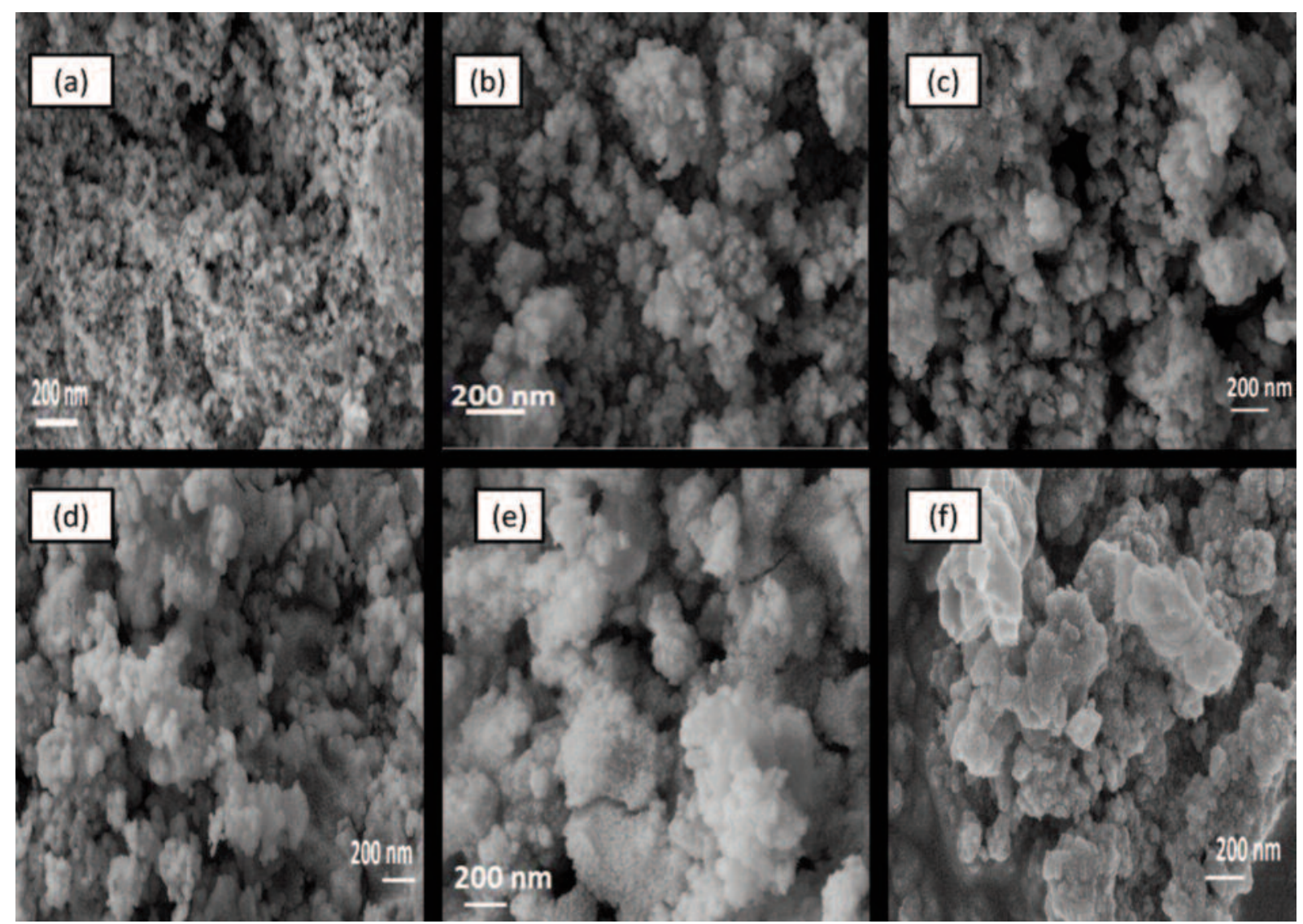

Figure 4: SEM images of (a) $\mathrm{ZrO}_{2}$, (b) $\mathrm{S}-\mathrm{ZrO}_{2}$ and (c) $\mathrm{P}-\mathrm{ZrO}_{2}$ un-aged nanoparticles and their respective aged nanoparticles (d) $\mathrm{ZrO}_{2}$, (e) $\mathrm{S}-\mathrm{ZrO}_{2}$ and (f) $\mathrm{P}-\mathrm{ZrO}_{2}$ 
analysis (see Figure 5). All nanoparticles exhibited a spherical morphology with a particle size diameter which is narrowly dispersed. The un-aged nanoparticles have a particle size distribution of $20-30 \mathrm{~nm}$. The aged nanoparticles had a particle size of 10-13 $\mathrm{nm}$. These results are in agreement with the BET results. Figure 5 (g-i) shows that the nanoparticles are crystalline, which was also confirmed by XRD results.

\section{Conclusion}

The $\mathrm{ZrO}_{2}$ nanoparticles were successfully synthesised with varying sizes. The ageing method shows that the single phase of $\mathrm{ZrO}_{2}$ nanoparticles can be obtained by a simple ageing method at ambient temperatures, which will reduce costs, given that previous researchers have synthesised this single phase at temperatures above $950{ }^{\circ} \mathrm{C}$. This tetragonal phase is useful in catalysis and makes these nanoparticles suitable for use in the Nafion membranes used in fuel cells. The sulphated and phosphated $\mathrm{ZrO}_{2}$ has been found by other researchers to be suitable for the fuel cell membrane due to their acidic sites. The nanoparticles produced in this work had large pore volume and smaller particle size, which is also useful in fuel cell membrane due to their high capacity for water retention. The ageing method has shown that it is possible to produce small particle size with a higher surface area and single phase (tetragonal) zirconia which is suitable in the fuel cell membrane application.

\section{Acknowledgements}

The authors thank Dr James Wesley-Smith for the SEM and TEM results. The financial support of the National Research Foundation, the University of the Witwatersrand, and the Council for Scientific and Industrial Research is acknowledged.

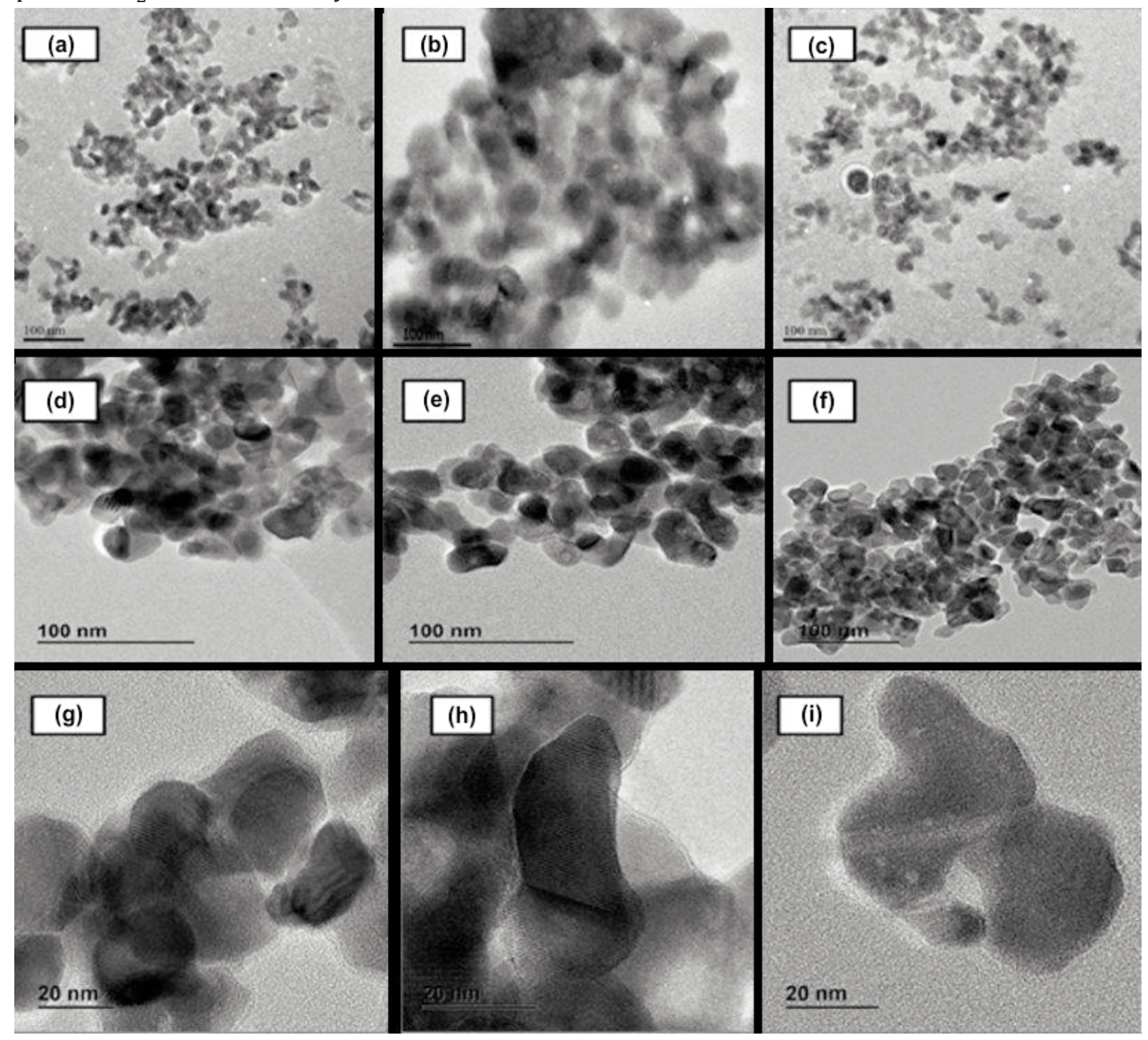

Figure 5: TEM images of (a) $\mathrm{ZrO}_{2}$, (b) S- $\mathrm{ZrO}_{2}$ and (c) $\mathrm{P}-\mathrm{ZrO}_{2}$ un-aged nanoparticles and their respective aged nanoparticles (d) $\mathrm{ZrO}_{2}$, (e) $\mathrm{S}-\mathrm{ZrO}_{2}$, (f) $\mathrm{P}-\mathrm{ZrO}_{2}$ (g) $\mathrm{ZrO}_{2}$, (h) $\mathrm{S}-\mathrm{ZrO}_{2}$ and (i) $\mathrm{P}-\mathrm{ZrO}_{2}$ 


\section{References}

Abbattista, F., Delastro, A., Gozzelino, G., Mazza, D., Vallino, M., Busca, G. and Lorenzelli, V. 1990. Effect of phosphate ions on the surface chemistry and microstructure of amorphous alumina. Journal of the Chemical Society, Faraday Transactions 86:36533658.

Adamski, A., Jakubus P., Zolka, Z. 2008. Structural and textural evolution of zirconia nanocrystals induced by thermal treatment. Material science - Poland 26:273-380.

Adjemian, K. T., Lee, S. J., Srinivasan, S., Benziger, J. and Bocarsly, A. B. 2002 a. Silicon oxide Nafion composite membranes for proton-exchange membrane fuel cell operation at $80-140^{\circ} \mathrm{C}$. Journal of the Electrochemical Society 149:A256-A261.

Adjemian, K. T., Srinivasan, S., Benziger, J. and Bocarsly, A. B. 2002 . Investigation of PEMFC operation above $100{ }^{\circ} \mathrm{C}$ employing perfluorosulfonic acid silicon oxide composite membranes. Journal of Power Sources 109:356-364.

Adjemian, K. T., Dominey, R., Krishnan, L., Ota, H., Majsztrik, P., Zhang, T., Mann, J., Kirby, B., Gatto, L., Velo-Simpson, M., Leahy, J., Srinivasant, S., Benziger, J. B. and Bocarsly, A. B. 2006. Function and characterization of metal oxide-Nafion composite membranes for elevated-temperature $\mathrm{H}_{2} \mathrm{O}_{2} \mathrm{PEM}$ fuel cells. Chemistry of Materials 18:2238-2248.

Bondars, B., Heidemane, G., Grabis, J., Laschke, K., Boyesen, H., Schneider, J. and Frey, F. 1995. Powder diffraction investigations of plasma sprayed zirconia. Journal of Material Science 30:1621-1625.

Casciola, M., Capitani, D., Comite, A., Donnadio, A., Frittella, V., Pica, M., Sganappa, M. and Varzi, A. 2008. Nafion-zirconium phosphate nanocomposite membranes with high filler loadings: conductivity and mechanical properties. Fuel Cells 8: 217-224.

Costamagna, P., Yang, C., Bocarsly, A. B. and Srinivasan, S. 2002. Nafion ${ }^{\circledR} 115$ /zirconium phosphate composite membranes for operation of PEMFCs above $100{ }^{\circ} \mathrm{C}$, Electrochimica Acta 47:1023-1033.

Chuah, G. K., Jaenike, S., Cheong, S. A. and Chan, K. S. 1996. The influence of preparation conditions on the surface area of zirconia. Applied Catalysis A: General 145: 267-284.

Chuah, G. K., Liu, S. H., Jaenicke, S. and Harrison, L. J. 2001. Cyclisation of citronellal to isopulegol catalysed by hydrous zirconia and other solid acids. Journal of catalysis 200: 352-359.

Hara, S. and Miyayama, M. 2004. Proton conductivity of superacidic sulfated zirconia. Solid State Ionics 168: 111-116.

Hsieh, H. P. 1996. Inorganic membranes for separation and reaction, Amsterdam: Elsevier.

Jakubus, P., Adamski, A., Kurzawa, M. and Sojka, Z. 2003. Texture of zirconia obtained by forced hydrolysis of $\mathrm{ZrOCl}_{2}$ solutions. Journal of Thermal Analysis and Calorimetry 72:299-310.

Jian-Hua, T. Peng-Fei, G. Zhi-yuan, Z., Wen-hui, L. and Zhong-qiang, S. 2008. Preparation and performance evaluation of a Nafion- $\mathrm{TiO}_{2}$ composite membrane for PEMFCs. International Journal of Hydrogen
Energy 33:5686-5690

Jiao, X., Chen, D. and Xiao, L. 2003. Effects of organic additives on hydrothermal zirconia nanocrystallites. Journal of Crystal Growth 258:158-162.

Lim, H. S., Ahmad, A. and Hamzah, H. 2013. Synthesis of zirconium oxide nanoparticle by sol-gel technique. AIP Conference Proceeding 1571: 812816.

Kleina, L. C., Daikoa, Y., Aparicio, M. and Damay, F. 2005. Methods for modifying proton exchange membranes using the sol-gel process. Polymer 46: 4504-4509.

Mekhemer, G.A.H. and Ismail, H.M. 2000. Structure analysis of phosphated zirconia catalysts using XRD and nitrogen adsorption methods. Colloids and Surfaces A: Physicochemical and Engineering Aspects, 164:227-235.

Navarra, M. A., Abbati, C. and Scrosati, B. 2008 Properties and fuel cell performance of a Nafionbased, sulfated zirconia-added, composite membrane. Journal of Power Sources 183:109-113.

Parera, J. M. 1992. Promotion of zirconia acidity by addition of sulfate ion. Catalysis Today 15:481-490.

Ray, J.C., Pati, R.K. and Pramanik, P. 2000. Chemical synthesis and structural characterization of nanocrystalline powders of pure zirconia and yttria stabilized zirconia YSZ. Journal of the European Ceramic Society 20:1289-1295.

Ranjbar, M., Yousefi, M., Lahooti, M. and Malekzadeh, A. 2012. Preparation and characterization of tetragonal zirconium oxide nanocrystals from isophthalic icid-zirconiumIV nanocomposite as a new precursor. International Journal of Nanoscience and Nanotechnology 8: 191-196.

Roberts, M. J., Everson, R. C., Domazetis, G., Neomagus, H. W. J. P., Jones, J. M., Van Sittert, C. G. C. E., et al. Mathews, J. P., Density functional theory molecular modelling and experimental particle kinetics for CO2-char gasification. Carbon, 2015. 93(0): p. 295-314.

Roberts M. J., Everson R. C. , Neomagus H.W.J.P., Van Niekerk D. , Mathews J. P., Branken D. J. (2015) Influence of maceral composition on the structure, properties and behaviour of chars derived from South African coals. Fuel 142: 9-20.

Savadogo, O. 2004. Emerging membranes for electrochemical systems: Part II. High temperature composite membranes for polymer electrolyte fuel cell (PEFC) applications. Journal of Power Sources 127:135-161.

Shao, Z., Xu, H., Li, M. and Hsing, I. 2006. Hybrid Nafion-inorganic oxides membrane doped with heteropolyacids for high temperature operation of proton exchange membrane fuel cell. Solid State Ionics 177:779-785.

Smitha, V. K., Suja, H., Jacob, J., Sugunan, S. 2003. Surface properties and catalytic activity of phosphate modified zirconia. Indian Journal of Chemistry 42A:300-304.

Setare, E., Raeissi, K., Golozar, M. A. and Fathi, M. H. 2009. The structure and corrosion barrier performance of nanocrystalline zirconia electrodeposited coating. Corrosion Science 51:1802-1808. 
Stoychev, D., Ikonomov, J., Robinson, K., Stefanov, P., Stoycheva, M. and Marinova, Ts. 2000. Surface modification of porous zirconia layers by electrochemical deposition of small amounts of $\mathrm{Cu}$ or $\mathrm{Co}$ and $\mathrm{Co}^{+} \mathrm{Cu}$. Surface and Interface Analysis 30:6973.

Tanabe, K. and Yamaguchi, T. 1994. Acid-base bifunctional catalysis by $\mathrm{ZrO}_{2}$ and its mixed oxides. Catalysis Today 20:185-197.

Wang, S. F., Gu, F., Lü, M. K., Yang, Z. S., Zhou, G .J., Zhang, H. P., Zhou, Y. Y. and Wang, S. M. 2006.

Structure evolution and photoluminescence properties of $\mathrm{ZrO}_{2}: \mathrm{Eu}^{3+}$ nanocrystals. Optical Materials 28:1222-1226.

Wang, W., Guo, H. T., Gao, J. P, Dong, X. H. and Qin, Q. X. 2000. XPS, UPS and ESR studies on the interfacial interaction in $\mathrm{Ni}-\mathrm{ZrO}_{2}$ composite plating. Journal of Material Science 35:1495-1499.

Xu, W., Lu, T., Liu, C. and Xing, W. 2005. Low methanol permeable composite Nafion/ silica/ PWA membranes for low temperature direct methanol fuel cells. Electrochimica Acta 50:3280-3285.

Yadav, G. D. and Nair, J. 1999. Sulfated zirconia and its modified versions as promising catalysts for industrial processes. Microporous and Mesoporous Materials 33:1-48.

Zarubica, A., Jovic, B., Nikolic, A., Putanov, P. and Boskovic, G. 2009. Temperature imposed textural and surface synergism affecting the isomerization activity of sulfated zirconia catalysts. Journal of the Serbian Chemical Society 12:1429-1442.

Zawodzinski, T.A., Davey, J., Valerio, J. and Gottesfeld, S. 1995. The water content dependence of electroosmotic drag in proton-conducting polymer electrolytes. Electrochemica Acta 40:297-302.

Zhou, L., Xu, J., Li, X. and Wang, F. 2006. Metal oxide nanoparticles from inorganic sources via a simple and general method. Materials Chemistry and Physics 97:137-142. 